\title{
The Phenomenon, Slavoj Žižek: Deadly Jester or Thinker of our Age? ${ }^{1}$
}

\section{Ricardo Jose E. Gutierrez}

Sharpe, Matthew and Boucher, Geoff, Žižek and Politics (Edinburgh: Edinburgh University Press, 2010). 252 pp.

lmost 25 years ago, the Slovenian philosopher and psychoanalyst,
Slavoj Žižek broke through the intellectual crib of the Slovenian
academia. His inauguration in the English-speaking world was marked by the publication of his exceptional book The Sublime Object of Ideology. ${ }^{2}$ Today, his works "has made him one of the world's best-known public intellectuals," 3 even considered by many to be the thinker of our age. In fact, Foreign Policy honored him as one of its 2012's Top Global Thinkers, ${ }^{4}$ and more recently, Prospect has included him in the top 10 of its World Thinkers 2013. ${ }^{5}$ Žižek's growing corpus, already comprised of more than 50 published books and several hundred articles, continues to swamp Western Academia irrupting the commonly accepted premises with its unyielding counter-intuitive and radical analyses. His work oscillates around the dialectical interplay of high and low theory, ranging from the deployment of Hegelian Dialectics and Lacanian Psychoanalysis, to complex analyses of Hollywood and popular culture, down to his adamant critique of ideology, multiculturalism, liberalism, capitalism and the list goes on. Much of his success is rooted "in taking theory out of the ivory tower of

${ }^{1}$ See Adam Kirsch, "The Deadly Jester: Review of in Defense of Lost Causes," in New Republic (2 December 2008), <http://www.newrepublic.com/article/books/the-deadly-jester>. Also see Sean O'Hagan, "Slavoj Žižek: Interview" The Observer (27 June 2010), <http://www.theguardian.com/culture/2010/jun/27/slavoj-zizek-living-end-times>.

2 Slavoj Žižek, The Sublime Object of Ideology (London: Verso Books, 1989).

3John Gray, "The Violent Visions of Slavoj Zizek," in New York Review of Books, $<$ http://www.nybooks.com/articles/archives/2012/jul/12/violent-visions-slavoj-zizek/? pagination $=$ false $>$.

${ }^{4}$ See Alicia P.Q. Wittmeyer, "The FP Top 100 Global Thinkers," in Foreign Policy, $<$ http://www.foreignpolicy.com/articles/2012/11/26/the_fp_100_global_thinkers?page=0,55>.

5 See "World Thinkers 2013," in Prospect, <http://www.prospectmagazine.co.uk/ magazine/world-thinkers-2013/\#.Ut_p0tKwrZ4>.

(C) 2013 Ricardo Jose E. Gutierrez

http://www.kritike.org/journal/issue 13/gutierrez2 december2013.pdf

ISSN 1908-7330

(cc) BY-NC 
academia and into the world." 6 Indeed, this emerging thinker of our times is all the more much compelling and harder to neglect as he continues to give "voice to an era of absurdity." 7

Currently, Žižek holds major positions in different academic institutions. Among them are as a senior researcher at the Institute of Sociology of the University of Ljubljana in Slovenia, a professor of the European Graduate School and the International Director of the Birkbeck Institute for Humanities in London. Holding both doctorate degrees in Philosophy and in Psychoanalysis, Žižek's theoretical arsenal can be said to be composed of "three centers of gravity: Hegelian dialectics, Lacanian psychoanalytic theory, and contemporary critique of ideology." 8 In recent years, he has announced the uncompromising resuscitation and reinvention of Marxism in order to account for the serious predicaments the globe is experiencing today.

Žižek creatively reads the historical constellation in extensive scope and considerable precision, earning him different popular accolades or titles, such as, "Elvis of Cultural Theory," "9 "Academic Rock-Star,"10 "Intellectual Celebrity,"11 "Deadly Jester," or "The Most Dangerous Philosopher in the West."12 But obviously, Žižek's ever-rising popularity has gained him a split reception: he is either a theatrical buffoon or a serious philosopher.

On the one hand, due to his infamous reputation, he is now beginning to be taken as an amusing clown who pulls bad jokes from out of his hat. ${ }^{13}$ In fact, he will be releasing a book about his jokes this $2014 .{ }^{14} \mathrm{He}$ is,

${ }^{6}$ Santiago Zabala, "Slavoj Žižek and the Role of the Philosopher," in Al Jazeera (25 December 2012), <http://www.aljazeera.com/indepth/opinion/2012/12/20121224122215406939. html>.

${ }^{7}$ Ibid.

8 Slavoj Žižek, For They Know Not What They Do: Enjoyment as a Political Factor (London: Verso Books, 1991), 3.

${ }^{9}$ Scott McLemee, "Žižek Watch," in The Chronicle of Higher Education (6 February 2004).

${ }^{10}$ Eugene McCarrahar, "All Things New: A Review of The Fragile Absolute," in In These Times.com (26 June 2000), <http://inthesetimes.com/issue/24/15/mccarraher2415.html>.

${ }^{11}$ Rebecca Mead, "The Marx Brother: How a Philosopher from Slovenia Became an International Star," in New Yorker, 79:10 (5 May 2003).

12 Philipp Oehmke, "The Most Dangerous Philosopher in the West: Welcome to the Slavoj Žižek Show," in Spiegel Online International (08 July 2010), $<$ http://www.spiegel.de/international/zeitgeist/the-most-dangerous-philosopher-in-the-westwelcome-to-the-slavoj-zizek-show-a-705164.html>.

13 Zizek constantly reminds his audience, most especially during lectures or interviews that he should be taken seriously. He is very aware of the media's apparent strategy to create a particular image of him in the public space. And this is particularly what he is afraid of. In his movie Zizek! By Astra Taylor, he claims that "My big worry is not to be ignored, but to be accepted." See Astra Taylor, Zizek! (Zeitgeist Films, 2005).

(c) 2013 Ricardo Jose E. Gutierrez http://www.kritike.org/journal/issue 13/gutierrez2 december2013.pdf ISSN 1908-7330 


\section{SLAVOJ ŽIŽEK}

nonetheless, aware that this popular caricature is meant to obscure his philosophical project, dismissing his radical discontents about the present state of affairs all together. He conjectures "that making me popular is a resistance against taking me seriously." 15 Moreover, due to his playful approach to philosophy, his constant inclusion of jokes both in his published works and public lectures, he generates a public impression that he is not taking philosophy seriously. ${ }^{16}$

On the other hand, there are serious academics that either consider Žižek as someone "to be celebrated for keeping open the possibility of an emancipatory political alternative," 17 or as someone to be denounced as having totalitarian nostalgias, utopian and violent visions, disregard for academic seriousness, moral insensitivity, obscure theoretical gymnastics, even relentless publication of more books than he can still read through the modern procedure of cutting-and-pasting from his other works. ${ }^{18}$ Whether these judgments from the academic world are informed by the spirit of debate and association ${ }^{19}$ or outright dismissal of his work as "empty posturing" and obscurantist articulation, ${ }^{20}$ the growing critical reactions to

${ }^{14}$ Slavoj Žižek, Žižek's Jokes (Cambridge MA: MIT Press, 2014).

${ }^{15}$ Taylor, Zizek!.

16 Todd McGowan raises the issue on what level should we take Žižek seriously. He asks: "Does it mean, as an interview with Žižek on Radio France has suggested, that Žižek's thought is 'pop philosophy'?" See Todd McGowan, "Serious Theory," in International Journal of Zizek Studies, 1:1 (2007), 1.

17 Matthew Sharpe and Geoff Boucher, Žižek and Politics (Edinburgh: Edinburgh University Press, 2010), 1-2.

${ }^{18}$ Geoffrey Galt Harpham, "Doing the Impossible: Žižek and the End of Knowledge," in Critical Inquiry, 29:3 (2003), 453-485; John Gray, "The Violent Visions of Slavoj Zizek," in New York Review of Books, <http://www.nybooks.com/articles/archives/2012/jul/12/violent-visionsslavoj-zizek/?pagination=false>; John Holbo, "Zizek on Financial Collapse and Liberalism," in Crooked Timbers, <http://crookedtimber.org/2010/12/17/zizek-on-the-financial-collapse-andliberalism/>; Adam Kotsko, “The 'Christian Experience' Continues: On Žižek's Work Since the Parallax View," in International Journal of Žižek Studies, 4:4 (2010), 5.

${ }^{19}$ Consider some of the works of leading figures in Žižek studies that take his work with both rigor and critical analyses: Sarah Kay, Žižek: A Critical Introduction (London: Polity Press, 2003); Tony Myers, Slavoj Žižek: Routledge Critical Thinkers (London: Routledge, 2003); Ian Parker, Slavoj Žižek: A Critical Introduction (London: Pluto Press, 2004); Matthew Sharpe, Slavoj Žižek: A Little Piece of the Real (Aldershot: Ashgate, 2004); Rex Butler, Slavoj Žižek: Live Theory (New York: Continuum, 2005); Rex Butler, The Žižek Dictionary (Durham: Acumen Publishing, 2014); Marcus Pound, Žižek: A (Very) Critical Introduction (Wm. B. Eerdmans Publishing Co.: Grand Rapids Michigan, 2005); Jodi Dean, Žižek's Politics (London: Routledge, 2006); Adam Kotsko, Žižek and Theology (London and New York: T\&T Park, 2008); Adrian Johnston, Žižek's Ontology: A Transcendental Materialist Theory of Subjectivity (Illinois: Northwestern University Press, 2008); Adrian Johnston, Badiou, Žižek, and Political Transformations: The Cadence of Change (Illinois: Northwestern University Press, 2009); Jamil Kader and Molly Anne Rothenbeg eds., Žižek Now: Current Perspectives (Cambridge: Polity, 2013).

${ }^{20}$ The recent debate between Žižek and Chomsky centered on the latter's attack on the former's obscurantism in particular and Continental philosophy in general, which, in a

(c) 2013 Ricardo Jose E. Gutierrez

http://www.kritike.org/journal/issue 13/gutierrez2 december2013.pdf

ISSN 1908-7330

(cc) BY-NC 
and valorizations of his work is a testament to the emerging academic seriousness on Žižek. It is interesting to note that the international journal established in dedication to his works, the International Journal of Žižek Studies (http://zizekstudies.org/), has become the promotional site of this same seriousness toward Žižek's works.

\section{Žižek and Politics A Substantial Contribution to Žižek Scholarship}

Among the growing scholarly oeuvre dedicated to Žižek scholarship, the recently published book Žižek and Politics is undeniably enthralling as it is both comprehensively informative and deliberately open for more critical assessment. Along with this book, the two authors, Matthew Sharpe and Geoff Boucher, are also separate authors of two other critical books dedicated to Žižek. ${ }^{21}$ Among others, their primary strategy, in contrast to the usual devout reader of Žižek, is to offer a kind of immanent critique that drives Žižek's message to its utmost possible conclusion in relation to both the structure of his thought and the historical milieu it is being enunciated. This strategy is as daring as it is creative and productive, for while it thinks with Žižek, it deliberately uproots him from his comfortable subjective space, forcing him to look at his own self. In other words, Žižek and Politics constrains Žižek and forces him to examine the proverbial eye that sees all things except itself.

The introductory part alone of Žižek and Politics will leave any reader with a stunning impression of the extensive scope of its subjectmatter. In addition, it was able to condense both depth and accessibility in its attempt to elucidate and make sense of Žižek's erratic compositions. Although reserved with its fundamental aim, it is bolder in its assertions and trajectory. Both as a critical introduction and a cognitive mapping of Žižek's theoretical work, it strived to trace the critical points, palpable dilemmas, internal deadlocks, and lucrative regions for both fanatics and scholars alike.

In a somehow derisive but dynamic approach, Žižek and Politics, using the same strategy of Hegel's radicalization of Kant's epistemological limitation, locates the growing division of scholars towards Žižek as constitutive of the Thing-Itself - as an inherent division within the heart of Žižek's project. The book's major claim is that, analytically speaking, there are two Žižeks: "the Radical-Democratic 'Žižek1' and the Revolutionary-

way, at least for Chomsky, implies as empty posturing. For the transcript, see $<$ http://news.rapgenius.com/Noam-chomsky-chomsky-zizek-debate-annotated $>$.

${ }^{21}$ Sharpe, Slavoj Žižek: Litte Piece of the Real; Geoff Boucher, The Charmed Circle of Ideology: A Critique of Laclau and Mouffe, Butler and Žižek (Melbourne: RE Press, 2006).

(C) 2013 Ricardo Jose E. Gutierrez

http://www.kritike.org/journal/issue 13/gutierrez2 december2013.pdf

ISSN 1908-7330 


\section{SLAVOJ ŽIŽEK}

Vanguardist 'Žižek2'."'22 Whereas in some sense the division is overlapping due to presence of the same elements in both periods, the book argues that the radical shift is informed by the change in "the dominant structure of his [Žižek] thinking." 23

The ingenuity of the book is not so much due to its critical appraisal of the internal division within Žižek's work, ${ }^{24}$ but the fact that it is able to locate the "theoretical" basis for this radical shift: namely when Žižek had come across with the fragmentary works on theogony of the Romantic Philosopher, F.W.J. Schelling. Sharpe and Boucher maintain that after shutting himself up for almost two years (1994-1996), which is very uncharacteristic of Žižek, in 1996-1997 he emerged as a "changed man." 25 These were the years when the two treatises about Schelling were published: The Indivisible Remainder ${ }^{26}$ and The Abyss of Freedom. ${ }^{27}$

However, what is more crucial to consider is the chasm between the two positions that engendered parallel implications. Sharpe and Boucher hold that although these two positions that Žižek adopt have parallel trajectories, it still begins from the same starting point, namely, the fundamental problem of Žižek's work: "how do subjects get entangled in ideology in the first place?" In responding to this, Žižek, they claim, appraises that the key in understanding this predicament is to critically analyze the social ideals that the ideology promotes. ${ }^{28}$ Two options emerged for Žižek: one is to liberate the desire of the subjects from the ideological fantasies to promote the adoption of new symbolic identifications; and two is to liberate the drive of the subject through the performance of the act that will overthrow the existing ideology. ${ }^{29}$ From these two answers come, as they claim, the two divisions of both Žižek and the content of the book.

The first division explores in depth the nuances found in Žižek $1-$ the Žižek that pursues the liberation of the desire of the subjects. The discussion centers with the major contributions of Žižek in the field of

${ }^{22}$ Ibid., 24

${ }^{23}$ Ibid., 25. Emphasis added.

${ }^{24}$ In the film Žižek!, Žižek is obviously aware of the former position that he turned away from. While he maintains that Sublime Object is one of his best books, he acknowledges that he is still critical of it. Describing it, he said: "It's still too liberal. I'm for democracy there. I'm ashamed, I'm very sorry to say. I think there was a thing called totalitarianism, which was bad, and I think there should be pluralism in society. My God, what am I talking there?...If I were not myself, I would arrest myself." See Taylor, Žižek!,

${ }^{25}$ Sharpe and Boucher, Žižek and Politics, 111.

${ }^{26}$ Slavoj Žižek, The Indivisible Remainder: An Essay on Schelling and Related Matters (London and New York: Verso Books, 1996).

27 Slavoj Žižek and F.W.J. von Schelling, The Abyss of Freedom and the Ages of the World (London and New York: Verso Books, 1997).

${ }^{28}$ Sharpe and Boucher, Žižek and Politics, p. 12.

${ }^{29}$ Ibid., 13.

(C) 2013 Ricardo Jose E. Gutierrez

http://www.kritike.org/journal/issue 13/gutierrez2 december2013.pdf

ISSN 1908-7330

(cc) EY-NC 
political philosophy, namely, his "rehabilitation of the notion of the modern subject," 30 his theory of ideology, and his typological distinction of political regimes. The authors argue that Žižek calls for a reanimation of the "unacknowledged kernel" 31 of the Cartesian subject that was buried by the post-structuralist, anti-Enlightenment philosophers. Through the Lacanian reading, Žižek shifts the reading from the substantial totalizing Ego and the discursive Self, to the 'Cartesian subject' that is void, empty, nonsubstantial. For Žižek "the subject is 'split' even if there is only one unified 'Self', since this split is the very split between [the Cartesian subject] and Self...." 32 Along these lines, Sharpe and Boucher, then, link this reading as to how this kind of subject relates to their reading of Žižek's theory of ideology.

The kernel of Žižek's theory of ideology is the key insight that 'enjoyment,' using the psychoanalytic sense of the term, is a major political factor. The authors claim that Žižek wonders as to the reason why, even if the subjects are already disillusioned by the symbolic order containing a particular master signifier, they "do not necessarily adopt a new one." 33 But more problematically, even if they adopt a new one, they still, in a weird way, return to uphold the old social ideals. Žižek's answer is clear: jouissance or enjoyment. For Žižek, this ideological fantasy of enjoyment that takes hold over us, producing as a consequence our symbolic identity is a lure to the reification of ideologies. ${ }^{34}$ However, what this lure conceals is the incompleteness and non-existence of this ideological Other, for beneath it is the virtual presupposition of the dreaded Cartesian subject that is nonsubstantial, incomplete, and lacking in itself. In other words, only through the misperception and alienation of the subject does reification or "untouchable" status of ideology is sustained. What is needed is to include ourselves in our perception of ideology. To use Hegel's terms: "The Absolute is not only Substance, but equally as Subject." ${ }^{35}$ For Žižek, this names the "internal division of all such substances: their minimal incompletion and openness for future changes by us as subjects-the substance needs the subject who misrecognise how they can also always reshape it." 36

30 Ibid., 7.

${ }^{31}$ Ibid., 64.

${ }^{32}$ Cf. Slavoj Žižek, The Plague of Fantasies (London and New York: Verso Books, 1997),

141.

${ }^{33}$ Sharpe and Boucher, Žižek and Politics, p. 9.

${ }^{34} \mathrm{Ibid} ., 72$.

35 Cf. G.W.F. Hegel, The Phenomenology of the Spirit, trans. by A.V. Miller (USA: Oxford University Press, 1977), 10.

${ }^{36} \mathrm{Ibid}$.

(C) 2013 Ricardo Jose E. Gutierrez http://www.kritike.org/journal/issue 13/gutierrez2 december2013.pdf ISSN 1908-7330 


\section{SLAVOJ ŽIŽEK}

Subsequently, Sharpe and Boucher revisited Žižek's nifty re-reading of the different political regimes, most specifically the nature of fascism and Stalinism. Reading these regimes through the lens of Lacanian logic of desires, Žižek reads fascism as an attempt to revive the discourse of the Master in modern times. On the other hand, Stalinism together with consumerism, Žižek thinks, follows the discourse of the University. However, in the case of the former, it has gone mad. While the dominant trend labels both as embodiments of totalitarianism, Žižek finds this unconvincing and sweeping-even more so, it appears to be an ominous obfuscation of the emancipatory potential of Stalinism as a political regime.

Ultimately, the first part located Žižek's position in the RadicalDemocratic Left together with Laclau and Mouffe. What this position upholds is the remarkable idea brought about by modernity: the empty place of political power. This is the democratic element in their position. And "it is radical because it proposes to learn to live with antagonism." In other words, if one is to comprehend in the area of politics, it should be affirmed that "political antagonism is a universal part of political life," that it involves "a struggle between relatively universal 'master signifiers'." ${ }^{37}$ By fully acknowledging this position, Laclau and Mouffe, together with Žižek believe that one is able to liberate desire from the 'Thing' - the elusive and illusive object that can be said to extinguished desire-or in political terms, the utopia of a paradise of full harmony and complete peace. In replacement, desire, then should be focused on the promotion of adopting new relatively universal 'master signifiers' to renew and reform the social ideals of the existing order.

For Sharpe and Boucher, this position is an attempt to continue the Enlightenment project of championing Reason to understand the unconscious. In this particular case, subjects, by traversing the fantasy of utopia, realizes that they live in an open order where finite and divided subjects are the ones who organize society. Consequently, this means that what are needed are self-determined rational and autonomous subjects to understand the workings and problems of society to provide solutions and reforms.

In between the two major parts of the book is what Sharpe and Boucher call the "vanishing mediator" of the two parts. Here, it unveils its most interesting contribution to Žižek scholarship: the rendezvous with the Romantic philosopher F.W.J. Schelling. Accordingly, for the authors, this untimely meeting registers a different and thoroughly problematic account of subjectivity. In contrast to the victory of reason over the unconscious in

${ }^{37}$ Sharpe and Boucher, Žižek and Politics, 109.

(C) 2013 Ricardo Jose E. Gutierrez

http://www.kritike.org/journal/issue 13/gutierrez2 december2013.pdf

ISSN 1908-7330

$(\mathrm{cc}) \mathrm{BY}-\mathrm{NC}$ 
Žižek1, Žižek2 endorses a kind of "moral theory of authenticity" 38 by being true the real kernel of existence, the death-drive.

Following Schelling's theogony, Žižek2, according to Sharpe and Boucher, offers a speculative account of the beginnings of the subject. For them, Žižek2 provides a theory of the subject that can be said to be a "worldgenerating entity with godlike powers," 39 for it is the subject, in its attempt to escape the vortex of drives, who creates political regimes with its radical founding act. ${ }^{40}$ What this ultimately suggests is that Žižek2 endorses an identical subject-object in the guise of a meta-subject that simply externalizes itself to produce the Other or symbolic order. For Sharpe and Boucher, the most alarming implication of this procedure is that Žižek2 can short-circuit the analyses of different fields using the same universal method: Lacanian psychoanalysis. It is as if Žižek2, by presuming that even the symbolic order is a by-product of the subject, can simply analyze all the multiple theoretical fields generated by this Other using only one method because he thinks they share one and the same-structure. ${ }^{41}$ Sharpe and Boucher even argue that the paratactic procedure Žižek is using is a strategy for him to jump "between radically different fields," from philosophy to politics, then to cinema. And what justifies intellectually this strategy is the silent assumption that every theoretical field has the same structure: the identical subject-object of the Žižekian subject. ${ }^{42}$

The second major part of the book takes off along with the metamorphosed subject of the later Žižek. Likewise, part two also elaborates on three different accounts developed by Žižek in his works: psychoanalytic reading of late-capitalism, his account of the necessity of the notion of the act to "re-start history," 43 and his uncanny and pessimistic account of political theology.

It begins with the characterization of our contemporary period as "reflexive modernity." 44 This is characterized by a "new epoch of freedom" 45 where people understands that the project of life is self-realization released from the constraints of tradition enabling them to choose from a plurality of identities. This has two serious implications: the decline of the paternal authority and the rise of the maternal super ego. While it rejects the authoritarian spirit and valorizes libertarian revolt and individualism, for Žižek it is "incomparably more oppressive" because it imposes enjoyment as

\footnotetext{
${ }^{38} \mathrm{Ibid} ., 116$

${ }^{39}$ Ibid., 118

${ }^{40}$ Ibid., 119.

${ }^{41}$ Ibid., 27.

42 Ibid., 125

${ }^{43}$ Ibid., 166.

${ }^{44}$ Ibid., 141.

${ }^{45}$ Ibid., 142.
}

(c) 2013 Ricardo Jose E. Gutierrez http://www.kritike.org/journal/issue 13/gutierrez2 december2013.pdf ISSN 1908-7330 
an imperative. ${ }^{46}$ Deprived of it, you diminish into the less privileged. As a consequence, for Žižek reflexive modernity ensues "the collapse of the big Other and the uncontested hegemony of global capitalism." 47 And this breeds more effects: on the one hand, the collapse of the big Other, in effect, triggers the destitution of communal and customary norms; on the other hand, the uncontested hegemony of global capitalism not only forces you to enjoy and fashion yourself according your self-expression, but more problematically, it reifies the liberal consensus of the End of History.

Through this scheme engendered by liberal capitalism, they were successful in portraying a convincing line of division between liberalism against totalitarianism and fundamentalism. This liberal capitalist blackmail not only satisfies its consumers with the logic of self-fashioning, but also hinders any attempt for radical political changes due to its totalitarian potentialities. Ultimately, for Žižek, this leads to a post-political age, where even the most radical leftists acknowledge liberal capitalism as an unsurpassable horizon of history. All we can do now is simply to bombard it with impossible demands. For the authors, although Žižek progressively reads this timely consensus, he remains stuck in this logic, thereby arguing, in a reactionary way, against this liberal blackmail. Accordingly, to confront this post-political obfuscation, Žižek endorses a true political change through the radical political act, which can re-start history.

Grounded in the notion of the 'god-like' subject filled with deathdrive that can be totally detached from historical and collective forces, for Sharpe and Boucher, Žižek can easily conceive a re-writing of a new symbolic order. Moreover, politically speaking, with the growing discontent from all the current political positions, ${ }^{48}$ Žižek, as an alternative, "endorses a politics of (death) drive, an active will to disrupt" to contest the neutral rules of liberal political opinions. ${ }^{49}$ This project seeks to traverse the fantasy of the current political regime and replace it with another fundamental fantasy "built around the former regime's exception or sinthome."50 And for Žižek this exception is the truly universal position, which is embodied by the re-invented notion of the proletarian, the "part of no part" in society: "although they are parts of the exiting order, they are absolutely unrecognized." ${ }^{11}$ But this can only be done through the "dictatorship" of the

${ }^{46}$ Cf. Slavoj Žižek, Looking Awry: An Introduction to Jacques Lacan through Popular Culture (Cambridge, MA: MIT Press), 102-03.

${ }^{47}$ Sharpe and Boucher, Žižek and Politics, 148.

${ }^{48}$ Ibid., 67.

${ }^{49}$ Ibid., 175.

${ }^{50} \mathrm{Ibid}$.

${ }^{51} \mathrm{Ibid} ., 186$.

(c) 2013 Ricardo Jose E. Gutierrez

http://www.kritike.org/journal/issue 13/gutierrez2 december2013.pdf

ISSN 1908-7330

(cc) BY-NC 
excluded. In a sense, Žižek is endorsing an authoritarian and reactionary ${ }^{52}$ position that hopes to usurp the existing order.

Along the same lines of the subject of death-drive, Sharpe and Boucher appraise Žižek's turn to political theology. For the authors, this implies a Hobbesian understanding of society. ${ }^{53}$ For Žižek, the solution is a Christian solution: a stubborn attachment to a Cause, elevated to the Thing, through love. ${ }^{54}$ What this love entails is a love beyond the law in the name of a higher purpose or ethical teleology. ${ }^{55}$ This creates a communal solidarity among the collective turning their death-drive against the current order. The problem for Sharpe and Boucher is that "Žižek has no concrete vision of a better world" only the appeal to risk it out of authenticity to our death-drives. ${ }^{56}$

In conclusion, they highlighted Žižek's betrayal of his philosophical and political masters. For them Žižek falls victim to a Lacanian psychoanalytic overstretch, anti-Hegelian irrationalism, and the disloyalty to, even caricaturing of Lenin. ${ }^{57}$ And their solution against Žižek's metaanalyses of identical subject-object is to diversify and embrace a multidimensional and interdisciplinary critical theory to challenge the chaotic specialization of neoliberalism. ${ }^{58}$ This position hopes to counteract the tconception of philosophers as the enlightened ones and the people are simply ideologically duped residing in the cave. In other words, Sharpe and Boucher believe in the capacity of the people to understand their own social reality so as to address the critical issues at hand.

\section{Observations and Disagreements in the Spirit of Debate}

What became obvious in the second part of Žižek and Politics is the exaggerated tone and the desperate attempt to show the 'traumatic' side of the subject of death-drive. Unlike the lucrative and neat first part that fills you in with substantial knowledge about Žižek's work in general, the second part becomes a very predictable and a highly suspicious reading. The pessimism bred an obvious woebegone despondence by an obvious vacillation of criticism from one issue to another to the point of being reductive and objective, which loses the philosophical spirit of the work.

\footnotetext{
52 Ibid., 193.

53 Ibid., 215.

${ }^{54}$ Ibid., 208.

55 Slavoj Žižek, The Puppet and the Dwarf: The Perverse Core of Christianity (Cambridge, MA: MIT Press, 2003), 112.

${ }^{56}$ Ibid., 217.

${ }^{57}$ Ibid., 225-231.

${ }^{58}$ Ibid., 232.
}

(C) 2013 Ricardo Jose E. Gutierrez http://www.kritike.org/journal/issue 13/gutierrez2 december2013.pdf ISSN 1908-7330 


\section{SLAVOJ ŽIŽEK}

Perhaps out of the desperation to offer a solution, they simply turn to the same postmodern position that endorses the multiplicity of centers irreducible to any meta-language; and what seals this obvious desperation is their appeal to the scientific sociological studies ${ }^{59}$ of time immemorial to reduce Zizek's project to the level of probability. The authors suddenly sounded quite unconvincing in terms of structure and argumentation. Even though the introduction was already hinting on the upcoming elation of how, from the more lucrative and placid part one, it will enter the true battle field of critique in part two, the book gradually lost its charm when it tried to show its reductions, alternatives, and little (mis)readings. I think the problem can be appraised from at least three things: entanglement with the two major divisions of Žižek, inability to think the Event, and scientific reductionism.

Against the authors' anticipated consensus about the response to the division of Žižek's work of reductionism, I still think it is productive. The problem lies elsewhere, namely they were trapped within their own distinction, as if there Žižek2 signals the point of no return to Žižek1. This is the reason why they were able to misread the Žižekian subject altogether. Arriving at the conclusion that Žižek's subject is a meta-subject generating all reality is already a little too much to consider. But to think that the authors misread it as such is more problematic. Žižek writes: "the 'subject' is not a substantial agent generating all reality, but precisely the moment of cut, failure, finitude, illusion, 'abstraction'."60 And this position is entirely related to the subject of Žižek1. Through this radical distinction of Žižek1 from Žižek2, they were not able to see the more profound implication of Žižek's turn to Schelling by reading it side-by-side with the revival of the Cartesian subject of the earlier Žižek.

This turn to Schelling and viewing the subject as like God does not automatically imply the subject as having godlike powers. Instead, what he finds in Schelling is not the ability of the subject to pre-exist the symbolic order as such, but the inability of the subject to be a subject without the symbolic order. While the Cartesian subject discloses that it is only through the belief of subjects that the symbolic order exists, Schelling was able to add that "if a subject were to suspend its belief in the big Other, the subject itself, its 'reality' would disappear," 61 that is, relegated to the level of blind drives.

The other more crucial reading that Schelling opens up is the primordial freedom of death-drive inherent in the subject that irrupts the symbolic order. And this, I think, is the dimension that they are founded on,

${ }^{59}$ Ibid., 129.

${ }^{60}$ Slavoj Žižek, Less than Nothing (London: Verso Books, 2012), 380, 406.

${ }^{61}$ Ibid., 92.

(C) 2013 Ricardo Jose E. Gutierrez

http://www.kritike.org/journal/issue 13/gutierrez2 december2013.pdf

ISSN 1908-7330

(cc) BY-NC 
which assumes the subject's godlike powers and the ability of the subject to become undivided. On the contrary, I think this only tells us of the possibility of the irruption of the symbolic order due to the subject as the moment of failure of the 'whole' or Other to be fully complete. This is also a testament to the split element in the subject and not its possibility to become a full subject in the Real or an 'acephalous saint.' ${ }^{62}$ While the Self of the subject is included in the symbolic order, the subject as void, as crack, has access to this primordial freedom not because it is all-too-powerful, but rather it is the moment of cut, of negation, of freedom outside the symbolic order-that it cannot fully symbolize the subject, that there remains an "indivisible remainder."

And this indivisible remainder, through a founding act, has the ability to negate the symbolic order to produce an Event-an un-signified, irrational possibility beyond the current symbolic order. It is only deemed irrational because it is un-signified and it is only un-signified because it escapes the current symbolic signification or discursive empirical knowledge of the existing order. And this is what the authors were not able to think through, given that even in the index of Žižek and Politics, Event, as a crucial notion in Žižek, was not even mentioned.

But to make this clear, Žižek does not read the Event as something entirely new, but rather a product or 'determinate negation,' ${ }^{63}$ a lost cause obfuscated by the same historical milieu- "the New of the Past itself." 64 Following Hegel, what Žižek never fails to remind us is that we cannot step out of our own history. This is why we should never read Žižek's subject as an all-powerful meta-subject that creates ex nihilo like God, but its power comes from its capacity to violently negate and tear apart what exists as given and appears substantial. For Žižek what makes the Event appear ex nihilo is its ability to re-organize the coordinates of the existing order, thereby appearing, retroactively as entirely new. This is a reason why I would endorse to read Žižek1's subject as a compliment to the subject of Žižek2, for only if we follow this procedure do we correct the power of the subject-no longer as godlike, outside the symbolic order that can simply usurp it by tapping into the death-drive, but rather unable to be a subject without the symbolic order, tapping into death-drive, the power of negativity, to tear apart the existing violent order.

Now, as a response to the question of the authors: "why in heaven or on earth does Žižek think that Schelling's mythology concern God is essential for political philosophy and his own Leftist thought?"65 My answer

${ }^{62}$ Sharpe and Boucher, Žižek and Politics, 119.

${ }^{63}$ Slavoj Žižek, In Defense of Lost Causes (London: Verso Books, 2008), 399.

${ }^{64}$ Žižek, Less than Nothing, 322.

${ }^{65}$ Sharpe and Boucher, Žižek and Politics, 119.

(c) 2013 Ricardo Jose E. Gutierrez http://www.kritike.org/journal/issue 13/gutierrez2 december2013.pdf ISSN 1908-7330 


\section{SLAVOJ ŽIŽEK}

would be, first, only Schelling's account was able to show the necessity of the big Other-as constitutive of the subject itself. And two, because only Schelling's seemingly ridiculous account was able to show unambiguously the primordial freedom inherent in the subject beyond the Kantian distinction of noumenal and phenomenal freedom, not only to choose authentically its fundamental fantasy, but also to reveal itself as the extrarational crack unable to be fully accounted for by any symbolic order. Consequently, what this unveils is the possibility of an Event, in the Badiouan sense of the term, beyond the current symbolic signification.

As mentioned, the Event is the second crucial point missed by the authors. Only by understanding the Event can we contextually understand what Žižek means by a re-writing of history or an absolute break with everything that exists. ${ }^{66}$ It is beginning to appear now the necessity of the place of the Event in Žižek's work to be properly understood. And, for me, this was opened up by Schelling's account that would support Lacanian psychoanalysis in understanding why Žižek somehow irrationally insists on the founding act and the immersion on the primordial freedom of the deathdrive.

Before this, we may ask: "why does Žižek insists on the Event? Why does he endorse a radical founding act that will usurp the current order? Is this simply, as the authors of Žižek and Politics believe, to be only true and authentic within the inner core of our existence?" The problem, again, is that the authors were not able to emphasize and account in detail the existing political and historical events happening today. Although they mentioned some, their purpose was not to situate them within Žižek's project, but only to analyze them using Žižek's theoretical reading. In Living in the End Times (although it is already explicit in In Defense of Lost Cause), Žižek already announced what necessitates this collective act: "the global capitalism is approaching an apocalyptic zero-point." 67 In shrugging this off, the authors got stuck on the side of political theory, ignoring the highly significant concrete features of our global order today.

This global crisis induced Žižek to turn to the possibility of collective action, dedicated to a Cause that will try to re-write the coordinates of the current order. In other words, only with a staunch engagement and fidelity to a Truth-Event ${ }^{68}$ can we save ourselves from total destruction. What is utopian for Žižek is not the radical usurpation of the current symbolic order and the reinstitution of a new Master signifier. Instead, what is truly utopian is how the current order can solve its own problems, save its own self from its self-destruction using its same

\footnotetext{
${ }^{66}$ Sharpe and Boucher, Žižek and Politics, 225.

${ }^{67}$ Žižek, Living in the End Times, $\mathrm{x}$.

${ }^{68} \mathrm{Ibid} ., \mathrm{xv}$.
}

(C) 2013 Ricardo Jose E. Gutierrez

http://www.kritike.org/journal/issue 13/gutierrez2 december2013.pdf

ISSN 1908-7330

(cc) BY-NC 
procedures. Arguably, this may also be the reason why Žižek turned to the subject of drives in his later period, not only because he met Schelling, but because some historical and political factors forced him to understand that we are engaged in an interminable crisis that the current order can no longer respond to.

It is interesting to note that Žižek's provocative language may have confused the authors particularly the terms "re-writing history and a real break from the existing order" and the like. But Žižek does not mean that we start from scratch. What Žižek implies is the possibility of the TruthEvent. The power of the Truth-Event is its capacity to re-configure or rearrange and ultimately re-write how we understand the flow of history. This acknowledgement of the gap between two regimes, the Old and the New, is what Žižek means by a total break from the old regime. Because for Žižek history is never linear, it consists of radical breaks. ${ }^{69}$

Finally, what attests to the authors' neglect of the Event leads me to my last observation: their scientific reductionism. I cannot hardly agree more with the authors' claim that "no major sociological theory of the last two hundred years has accepted that societies are created by virtue of political decisions." 70 Taking science as a frame of understanding is in fact a secure ground for analyses. My only problem with this is how they reduce the possibility to the level of science. And to reduce a philosophical discourse to the understanding of science is to overlook the possibility of the Event beyond the scope of the existing scientific research.

One might find it disappointing that two exceptional readers of Žižek missed the crucial point that Žižek has painstakingly tried to articulate throughout his works: he does not really offer a solution but rather acts as an analyst to provoke his readers. Although it is really a good point that they unveiled Žižek's silent presumption of using psychoanalysis as a meta-discourse to analyze everything, I think Žižek is doing this intentionally not out of academic irresponsibility, but for a more significant reason. I, however, acknowledge the importance, and I am in agreement with the authors, in addressing this crucial issue. While our world is dominated by the valorization of quantifiable scientific objective truth, I think Žižek sticks to the traditional notion of truth as truth-effect or an engaged truth, which, although based on absolute Faith, ${ }^{71}$ has the capacity

${ }^{69}$ See Žižek's analysis of the dialectic of the Old regime and the New regime in Less than Nothing, 272-273.

70 Sharpe and Boucher, Žižek and Politics, 129.

${ }^{71}$ This is the reason why in In Defense of Lost Causes, Žižek distinguishes doxa as mere empirical positive knowledge covered up by common sense of the current order from Truth as absolute Faith beyond common sense covered by scientific empirical positive knowledge of the current order.

(c) 2013 Ricardo Jose E. Gutierrez http://www.kritike.org/journal/issue 13/gutierrez2 december2013.pdf ISSN 1908-7330 


\section{SLAVOJ ŽIŽEK}

to change your whole being. ${ }^{72}$ To put it more objectively, even though the packaging of cigarettes admonishes you objectively with its empirical effects, it hardly changes your subjective consciousness about cigarettes. But an engaged truth, a powerful subjective truth of, for instance a devoted Pope to God or the writings of Nietzsche about greatness, changes your whole subjective consciousness even with the absence of objective, empirical data. This is the same truth that Žižek wants us to take from his writings. Like a psychoanalyst that does not really bother whether psychoanalysis is objectively valid as a science or not, his concern is to unleash a truth-effect that will change your whole subjectivity.

In contrast to Sharpe- and Boucher's interpretation of parataxis, I think it is also productive to consider the other side of the story. Žižek's parataxis arguably can be thought of as informed by this idea of truth-effect. The power of Zizek's discourse suffices for this kind of persuasion an analyst can bring about to an analysis and through his parataxical strategy of crisscrossing in different fields of learning to emphasize a specific point. Every reader of Žižek who takes him seriously sees this persuasive element in Žižek's ability to leap from low to high culture. This power to convince and unleash a truth-effect from his readers is also the way for him to mobilize his readers to gain fidelity to the Event, to the emancipatory element we need today.

Far from justifying Žižek from the scientific objectivity, the main point that I am trying to make is that there is an element of truth that we can garner from the long-forgotten qualitative discourse that philosophers hitherto channeled through civilizations that had a considerable impact around the globe. And this, I think, is what Žižek wants to communicate to his readers. As for the consequences of this procedure, we could say, at this juncture, as another subject for criticism.

Other than these major points, it is also worthwhile to point Sharpeand Boucher's understanding of Žižek's turn to theology. In contrast to their claim that it is just an evidence of his reactionary conservatism, I think Žižek is doing something more than this. In one of the interviews he had, Žižek pointed out that one of his disagreements with the French Philosopher, Alain Badiou is that the latter does not recognize and allow the theological and religious in the procedure of Truth-Event. ${ }^{73}$ And this theological dimension is what Žižek hopes to resuscitate in the contemporary period to contribute to the field of struggle. This is issue is not addressed in Žižek and Politics.

72 Žižek, Living in the End Times, xiii.

73 Slavoj Žižek, "An Interview with Slavoj Žižek On Divine Self-Limitation and Revolutionary Love," in Journal of Philosophy and Scripture, 1:2 (Spring 2004), 32.

(c) 2013 Ricardo Jose E. Gutierrez

http://www.kritike.org/journal/issue 13/gutierrez2 december2013.pdf

ISSN 1908-7330

$(\mathrm{cc}) \mathrm{BY}-\mathrm{NC}$ 
These observations and disagreements do not intend to defend Žižek's work, but to engage and contribute in the on-going critical debate regarding the importance (or lack of it) of Žižek's work. There is no doubt that Žižek and Politics is a substantial contribution to the field of Žižek scholarship. And my way of acknowledging this fact is to take this thoroughly serious through and through. With the privilege of reading the more recent works Žižek before reading Žižek and Politics, my observations may be worthwhile to be considered by the authors who painstakingly reconstructed Žižek's major project. Despite some fundamental disagreements with Žižek and Politics, I would not think twice in endorsing this work for scholars and students who are interested in Žižek's major political project.

The Graduate School, University of Santo Tomas, Philippines

\section{References}

“World Thinkers 2013," in Prospect, <http://www.prospectmagazine.co.uk/ magazine/world-thinkers-2013/\#.Ut_p0tKwrZ4>.

Boucher, Geoff, The Charmed Circle of Ideology: A Critique of Laclau and Mouffe, Butler and Žižek (Melbourne: RE Press, 2006).

Butler, Rex, Slavoj Žižek: Live Theory (New York: Continuum, 2005). The Žižek Dictionary (Durham: Acumen Publishing, 2014).

Dean, Jodi, Žižek's Politics (London: Routledge, 2006).

Gray, John, "The Violent Visions of Slavoj Zizek," in New York Review of Books, <http://www.nybooks.com/articles/archives/2012/jul/12/violen $\mathrm{t}$-visions-slavoj-zizek/? pagination=false $>$.

Harpham, Geoffrey Galt, "Doing the Impossible: Žižek and the End of Knowledge," in Critical Inquiry, 29:3 (2003).

Hegel, G.W.F., The Phenomenology of the Spirit, trans. by A.V. Miller (USA: Oxford University Press, 1977).

Holbo, John, "Zizek on Financial Collapse and Liberalism," in Crooked Timbers, <http://crookedtimber.org/2010/12/17/zizek-on-thefinancial-collapse-and-liberalism/>.

Johnston, Adrian, Badiou, Žižek, and Political Transformations: The Cadence of Change (Illinois: Northwestern University Press, 2009).

Žižek's Ontology: A Transcendental Materialist Theory of Subjectivity (Illinois: Northwestern University Press, 2008).

Kader, Jamil and Molly Anne Rothenbeg eds., Žižek Now: Current Perspectives (Cambridge: Polity, 2013).

Kay, Sarah, Žižek: A Critical Introduction (London: Polity Press, 2003).

(C) 2013 Ricardo Jose E. Gutierrez http://www.kritike.org/journal/issue 13/gutierrez2 december2013.pdf ISSN 1908-7330 


\section{SLAVOJ ŽIŽEK}

Kirsch, Adam, "The Deadly Jester: Review of in Defense of Lost Causes," in New Republic (2 December 2008), $<$ http://www.newrepublic.com/article/books/the-deadly-jester $>$.

Kotsko, Adam, "The 'Christian Experience' Continues: On Žižek's Work Since the Parallax View," in International Journal of Žižek Studies, 4:4 (2010).

Žižek and Theology (London and New York: T\&T Park, 2008).

McCarrahar, Eugene, "All Things New: A Review of The Fragile Absolute," in In These Times.com (26 June 2000), $<$ http://inthesetimes.com/issue/24/15/mccarraher2415.html>.

McGowan, Todd, "Serious Theory," in International Journal of Zizek Studies, 1:1 (2007).

McLemee, Scott, "Žižek Watch," in The Chronicle of Higher Education (6 February 2004).

Mead, Rebecca, "The Marx Brother: How a Philosopher from Slovenia Became an International Star," in New Yorker, 79:10 (5 May 2003).

Myers, Tony, Slavoj Žižek: Routledge Critical Thinkers (London: Routledge, 2003).

O'Hagan, Sean, “Slavoj Žižek: Interview" The Observer (27 June 2010), $<$ http://www.theguardian.com/culture/2010/jun/27/slavoj-zizekliving-end-times $>$.

Oehmke, Philipp, "The Most Dangerous Philosopher in the West: Welcome to the Slavoj Žižek Show," in Spiegel Online International (08 July 2010), <http://www.spiegel.de/international/zeitgeist/the-mostdangerous-philosopher-in-the-west-welcome-to-the-slavoj-zizekshow-a-705164.html>.

Parker, Ian, Slavoj Žižek: A Critical Introduction (London: Pluto Press, 2004).

Pound, Marcus, Žižek: A (Very) Critical Introduction (Wm. B. Eerdmans Publishing Co.: Grand Rapids Michigan, 2005).

Sharpe, Matthew and Geoff Boucher, Žižek and Politics (Edinburgh: Edinburgh University Press, 2010).

Sharpe, Matthew, Slavoj Žižek: A Little Piece of the Real (Aldershot: Ashgate, 2004).

Taylor, Astra, Zizek! (Zeitgeist Films, 2005).

Wittmeyer, Alicia P.Q., "The FP Top 100 Global Thinkers," in Foreign Policy, $<$ http://www.foreignpolicy.com/articles/2012/11/26/the_fp_100_glob al_thinkers?page $=0,55>$.

Zabala, Santiago, "Slavoj Žižek and the Role of the Philosopher," in $A l$ Jazeera (25 December 2012), $<$ http://www.aljazeera.com/indepth/opinion/2012/12/2012122412221 5406939. html>. 
Žižek, Slavoj and F.W.J. von Schelling, The Abyss of Freedom and the Ages of the World (London and New York: Verso Books, 1997).

Žižek, Slavoj and Noam Chomsky, <http://news.rapgenius.com/Noamchomsky-chomsky-zizek-debate-annotated $>$.

Žižek, Slavoj, "An Interview with Slavoj Žižek On Divine Self-Limitation and Revolutionary Love," in Journal of Philosophy and Scripture, 1:2 (Spring 2004).

For They Know Not What They Do: Enjoyment as a Political Factor (London: Verso Books, 1991). In Defense of Lost Causes (London: Verso Books, 2008). Less than Nothing (London: Verso Books, 2012). Looking Awry: An Introduction to Jacques Lacan through Popular Culture (Cambridge, MA: MIT Press). The Indivisible Remainder: An Essay on Schelling and Related Matters (London and New York: Verso Books, 1996). The Plague of Fantasies (London and New York: Verso Books, 1997).

The Puppet and the Dwarf: The Perverse Core of Christianity (Cambridge, MA: MIT Press, 2003). The Sublime Object of Ideology (London: Verso Books, 1989). Žižek's Jokes (Cambridge MA: MIT Press, 2014). 